
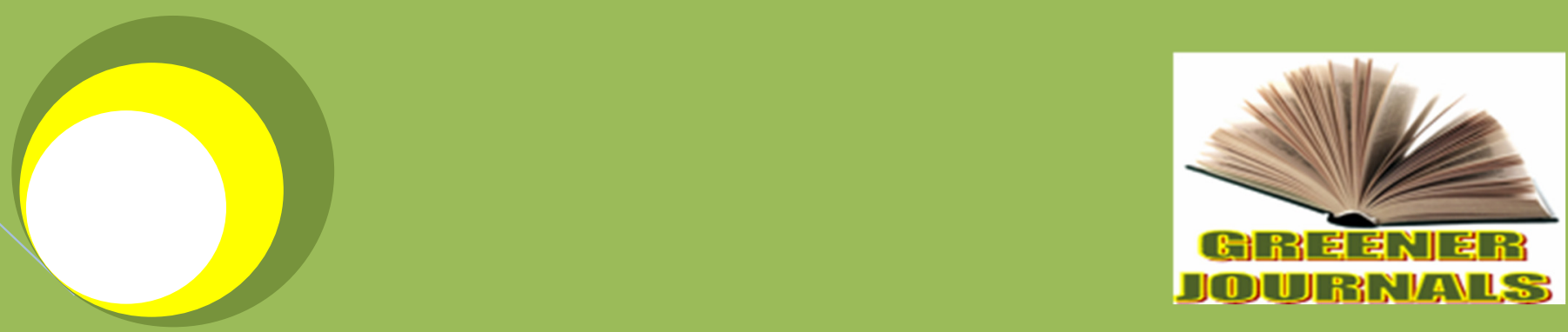

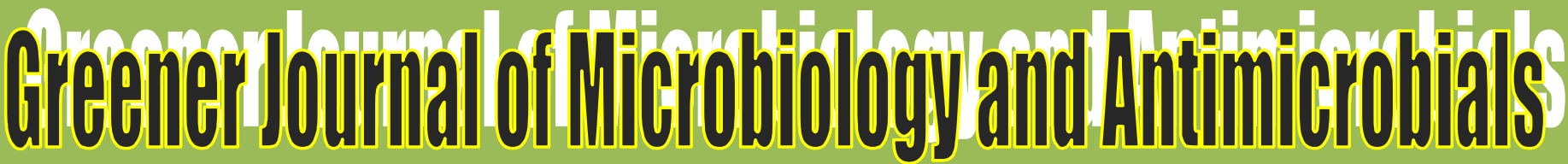

ISSN: 2354-2284

Submitted: 25/01/2017

Accepted: 27/01/2017

Published: 27/03/2017

DOI: http://doi.org/10.15580/GJMA.2017.1.012517009

Antimicrobial Activity

of the Leaf and Root

Extracts of Kigelia

africana and A/bizia

chevalieri against

Staphylococcus aureus

By

Samaila A.B.

Yarma A.A.

Oshomoh E.O.

Gabriel M.

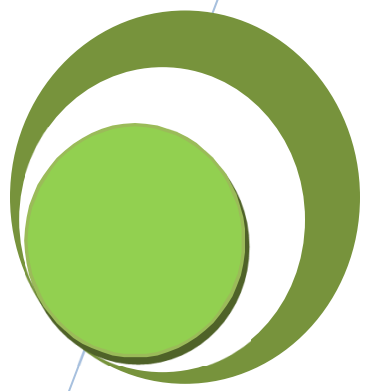




\title{
Antimicrobial Activity of the Leaf and Root Extracts of Kigelia africana and Albizia chevalieri against Staphylococcus aureus
}

\section{Samaila A.B. ${ }^{1 *}$, Yarma A.A. ${ }^{2}$, Oshomoh E.O. ${ }^{3}$ and Gabriel M. ${ }^{1}$}

\author{
${ }^{1}$ Department of Biological Sciences, Abubakar Tafawa Balewa University, PMB 0248, Bauchi State, Nigeria. \\ ${ }^{2}$ Yarma Memorial Hospital Gombe, Gombe State, Nigeria. \\ ${ }^{3}$ Department of Science Laboratory Technology, Faculty of Life Sciences, University of Benin, Edo State, Nigeria. \\ *Corresponding Author's Email: adamubsamaila13@yahoo.com, samailaadamub@ gmail.com \\ GSM: +2348033854269
}

\begin{abstract}
The investigation was carried out to determine the antimicrobial activity of the Leaf and Root extracts of Kigelia africana (nonon giwa) and Albizia chevalieri (katsari) against Staphylococcus aureus. Antimicrobial activity was evaluated by disc diffusion method and MIC and MBC were calculated by double fold dilution method. The antimicrobial activity result shows $20 \mathrm{~mm}$ zone of inhibition Kigelia africana leaf at $100 \%$ concentration and $16 \mathrm{~mm}$ zone of inhibition for albezia chevalieri leaf at same concentration while for the roots $14 \mathrm{~mm}$ and $11 \mathrm{~mm}$ zone of inhibition at $100 \%$ concentration. The maximum inhibition zone is found at $20 \mathrm{~mm}$ and minimum inhibition zone at $11 \mathrm{~mm}$. Also the antimicrobial result shows the MIC of $6.25 \mathrm{mg} / \mathrm{ml}$ against Staphylococcus aureus and MBC of $12.5 \mathrm{mg} / \mathrm{ml}$ and $10.5 \mathrm{mg} / \mathrm{ml}$ for both extracts. The study reveals that the extracts possess antimicrobial activity in a dose dependent manner. This antimicrobial activity may be due to the presence of some active compounds, further studies are highly needed for the drug development.
\end{abstract}

Keywords: Antimicrobial, Leaf, Root extracts, Kigelia Africana, Albizia chevalieri, Staphylococcus aureus.

\section{INTRODUCTION}

Nature has been a source of medicinal agents for thousands of years and an impressive number of modern drugs have been isolated from natural sources; many of these isolations were based on the uses of the agents in traditional medicine. This plant-based, traditional medicine system continues to play an essential role in health care, with about $80 \%$ of the world's inhabitants relying mainly on traditional medicines for their primary health care (Owolabi et al., 2007). According to World Health Organization, medicinal plants would be the best source to obtain a variety of drugs. Therefore, such plants should be investigated to better understand their properties, safety and efficacy (Nascimento et al., 2000). Long before mankind discovered the existence of microbes, the idea that certain plants had healing potential, indeed, that they contained what we would currently characterize as antimicrobial principles, was well accepted. The success story of chemotherapy lies in the continuous search for new drugs to counter the challenge posed by resistant strains of microorganisms.

With increase in antibiotic resistance, cost and inaccessibility (especially in rural areas) to some orthodox modern antibiotics, traditional weeds are fast gaining popularity even to urban and civilized dwellers. In addition, considering the wide medicinal application of this plant, this work was set out in order to investigate the antimicrobial activity of leaf extracts of $S$. obtusifolia against some pathogenic bacteria and fungi and to ascertain the chemical constituents that may be present. The use of modern separation techniques in the extraction and isolation of useful bioactive molecules from plant sources had made an otherwise tedious and time consuming process a lot easier (Constantine, 2007; Ankit et al., 2012).

Kigelia africana (Bignoniaceae) is a distinctive tree native to the African continent. The indehiscent, sausageshaped fruits, and less commonly the pale bark of roots and stems, are used in traditional medicines throughout its pan-continental distribution (Retief and Herman, 1997). The many uses of $K$. africana in therapy of physical and magico-religious or spiritual complaints indicate that this tree is a valuable and popular source of traditional medicine. 
Previous investigations of $K$. africana have established antimicrobial activity of the stem bark against Candida albicans, Pseudomonas aeruginosa, Bacillus subtilis, Escherichia coli and Staphylococcus aureus (Akunyili et al., 1991; Kwo and Craker 1996). Binutu et al. (1996) reported that extracts of $K$. africana roots and fruits showed antibacterial activity against Staphylococcus aureus, Bacillus subtilis, and antifungal effects against Aspergillus niger, Aspergillus flavus, Candida albicans and Pullularia pullularis. Anti-cancer potential has been indicated by cytotoxicity of root and bark material in the brine shrimp bioassay against Artemia salina (Khan, 1998; Ekeanyawu, 2011). Ankit, et al (2012) reported the significant inhibitory activity of stem bark extracts against four melanoma cell lines and a renal carcinoma cell line, and slight activity by fruit extracts. Azuine et al (1997) reported inhibitory effects of fruit extracts on induced tumors and inflammation in mice.

The plant Albizia chevalieri is a tree that grows up to $12 \mathrm{~m}$ high or a shrub under harsher conditions of the dry savannah from Senegal, Niger and Nigeria. It has an open and rounded or umbrella shaped canopy, bark palegreyish, twigs pubescent with white lenticels, leaves with 8-12 pairs of pinnate and 20-40 pairs of leaflets each. The bark was reported to contain alkaloids and also tannins sufficient for use in tanning in Nigeria and Senegal. It is used in Borno-North eastern Nigeria as purgative, taenicide and also remedy for coughs. A decoction of leaves is used in Northern Nigeria as remedy for dysentery (Burkill, 1995; Ahmed, et al., 2012).

This work was designed to investigate the antimicrobial properties of methanol leave and root extract of Albizia chevalieri and Kigelia africana with a view to assessing the inhibitory potentials of the plants against the test organism Staphylococcus aureus.

\section{MATERIALS AND METHODS}

\section{Plant Sample Collection}

The leaf and root of $A$. chevalieri (katsari) and $K$. africana (nonon giwa) was collected at Bauchi Local Government Area, Bauchi State of Nigeria in August, 2014; it was confirmed as A. Chevalieri (katsari) and K. africana in the department of Biological Sciences by a final year botany student. The sample was dried in the laboratory at room temperature and pulverized to powder with a pestle and mortal. The method of treatment followed standard procedures as recommended by Yusuf et al (2007); Igidi and Edene, 2014.

\section{Collection of test organism}

Clinical isolates was collected from ATBUTH in Bauchi town. The organism was subculture into nutrient agar prepared according to the manufacturer's instructions and sterilized at $121^{\circ} \mathrm{C}$ for 15 minute and incubated at $37^{\circ} \mathrm{C}$ for $24 \mathrm{hrs}$.

\section{Media for isolation}

The media used for the isolation of the organism was nutrient agar, prepared according to the manufacturer's instructions and sterilized at $121^{\circ} \mathrm{C}$ for 15 minutes.

\section{Media for maintenance}

The media used for maintenance of the test organism was Mueller Hinton agar, prepared according to manufacturer's instructions and sterilized at $121^{\circ} \mathrm{C}$ for 15 minutes. Suspension cultures of test bacteria were initiated from stock cultures maintained at $4^{\circ} \mathrm{C}$ on Mueller-Hinton (MH) agar.

\section{Preparation of antibiotic disc}

Whatman no.24, $6 \mathrm{~mm}$ diameter filter paper was used in the preparation of the paper disc; the filter paper was punctured into a circular disc of $6 \mathrm{~mm}$ in diameter and were put into a screw capped bottle and sterilized at $160^{\circ} \mathrm{C}$ for one hour.

\section{Preparation of Extract Using Maceration Method}

The leaves were separated and roots washed in clean water, and dried at room temperature (Eloff, 1998). $250 \mathrm{ml}$ of methanol was redistilled using distillation setup. $100 \mathrm{~g}$ of the powder was weighed on a balance in a beaker and soaked in $95 \% 250 \mathrm{ml}$ of methanol in a $500 \mathrm{ml}$ conical flask for 4 days (Prashant et al ., 2011 ). The filtrate was 
concentrated and dried in an oven at $45^{\circ} \mathrm{C}$ and dispensed into a sterile screw capped specimen bottle. This was kept in a refrigerator until required for use.

\section{Characterization and identification of the test organism}

Characterization was made by initial examination of the colonies on the plate, physiological examination such as staining reactions and biochemical test such as coagulase test and catalase test, were also carried out to aid identification of the organism.

\section{Evaluation of antimicrobial Activity of plant extracts}

The bioassay involves a simple disc diffusion test, for crude extract from each plant, dilution were made of alcoholic extract using methanol respectively. The dilution was made in the range of $10 \%$ to $100 \%$ and this was done by adding the crude extract to the solvent in the ratio of $10: 0,8: 2,6: 4$, and $4: 6$, for $100 \%, 80 \%, 60 \%$, and $40 \%$ respectively. The various dilutions were put in sterile specimen bottles with screwed caps.

The antimicrobial activity of $S$. aureus was evaluated using the Agar-disc diffusion method which was performed in accordance with the guidelines of National Committee for Clinical Laboratory Standards (NCCLS, 1990). An 18/24 hour old culture of selected bacteria was mixed with sterile physiological saline $(0.85 \%)$ and the turbidity was adjusted to 0.5 MacFarland ( 106 cfu/mL). Petri dishes containing $20 \mathrm{ml}$ of Mueller-Hinton agar was inoculated using standardized bacterial suspensions. Filter paper discs (Whatman no.24, $6 \mathrm{~mm}$ diameter) impregnated with the extracts at various concentrations by soaking discs for 10 Seconds in extract solution prepared, three disc of each were placed on the inoculated petri dishes and incubated for 24 hours after which inhibition zones were recorded in millimeters (Hemendra and Sushil, 2010). A positive control was set up using erythromycin and streptomycin and also a negative control in which the plates were uniformly sealed with the test organism and filter paper disc soaked in the solvent were incubated at $37^{\circ} \mathrm{C}$ for $24 \mathrm{hrs}$. Each extract was tested in triplicate (3 disc/plates).

\section{Determination of minimum inhibitory concentration (MIC), and minimum bactericidal concentration (MBC)}

The MIC was determined by serial dilution method using serially diluted plant extracts. MIC of the extracts was determined by dilution of the plant extract of various concentrations. Equal volume of each extract and Muller-Hinton Agar were mixed in the test tubes. Specifically $0.1 \mathrm{ml}$ of standardized inoculums was added to each test tube. The tubes were incubated at $37^{\circ} \mathrm{c}$ for 18-24 hours. Two control tubes were maintained for each test batch. This included antibiotic control (containing extract and growth media without inoculum) and organism control (tube containing the growth medium, saline and the inoculum).

The lowest concentration (highest dilution) of the extract that produced no visible bacterial growth (no turbidity) when compared with the control were regarded as MIC. However, the MBC were determined by subculturing the test dilution onto a fresh extract free solid medium and incubated further. The highest dilution that yielded no bacterial colony was taken as MBC.

\section{RESULTS}

The zone of inhibition of both plant extracts at $100 \%$ concentration were; table 1 for leaf of $K$. africana $20 \mathrm{~mm}$, table 2 for leaf of $A$. chevalieri $16 \mathrm{~mm}$, table 4 for root of same plant $11 \mathrm{~mm}$, and table 3 for root of $K$. africana $14 \mathrm{~mm}$, respectively. The antimicrobial test result below shows the susceptibility test against Gram positive bacteria $(S$. aureus).

Table 5 and 6 shows the MIC and MBC value of 6.25 and $12.5 \mathrm{mg} / \mathrm{mL}$ against Staphylococcus aureus for leave extract and 6.25 and 10.5, 6.25 and $12.5 \mathrm{mg} / \mathrm{mL}$ against Staphylococcus aureus for root extract tested and listed in the table below.

The low MIC value observed for $S$. aureus is a good indication of high efficacy against this bacterium. This outcome is remarkable considering that boil, breast abscess and surgical wound infection etc. (caused by $S$. aureus) is on the rise and also becoming recalcitrant to first-line antibiotics for its treatment in developing countries, including Nigeria. High MIC may be an indication of low efficacy or that the organisms have the potential for developing resistance to the bioactive compounds. 
Table 1. Antimicrobial activity measured by zone of inhibition $(\mathrm{mm})$ for methanol leave extract of $K$. africana

\begin{tabular}{|c|c|c|c|c|c|}
\hline Microorganism & $100 \%$ & $80 \%$ & $60 \%$ & $40 \%$ & $\begin{array}{l}\text { Standard/control } \\
1 \mathrm{mg} / \mathrm{ml}\end{array}$ \\
\hline Staphylococcus & 20.00 & 13.00 & 10.00 & 9.00 & 18(Erythromycin) \\
\hline
\end{tabular}

aureus

$$
\begin{gathered}
\text { Key:-ETM= erythromycin; } \\
\mathbf{R}=\text { Resistant Concentration of „a" control }=1 \mathrm{mg} / \mathrm{mL}
\end{gathered}
$$

Table 2. Antimicrobial activity measured by zone of inhibition ( $\mathrm{mm}$ ) for methanol leave extract of $\boldsymbol{A}$. chevalieri

\begin{tabular}{llllll}
\hline Microorganism & $\mathbf{1 0 0 \%}$ & $\mathbf{8 0 \%}$ & $\mathbf{6 0 \%}$ & $\mathbf{4 0 \%}$ & $\begin{array}{l}\text { Standard/control } \\
\mathbf{1 m g} / \mathbf{m l}\end{array}$ \\
Staphylococcus & 16.00 & 12.00 & 11.00 & 9.00 & 18 (Erythromycin)
\end{tabular}

aureus

Key:-ETM= erythromycin;

$\mathbf{R}=$ Resistant Concentration of „a" control $=1 \mathrm{mg} / \mathrm{mL}$

Table 3. Antimicrobial activity measured by zone of inhibition $(\mathrm{mm})$ for methanol root extract of $K$. africana

\begin{tabular}{lccccc}
\hline Microorganism & $\mathbf{1 0 0 \%}$ & $\mathbf{8 0 \%}$ & $\mathbf{6 0 \%}$ & $\mathbf{4 0 \%}$ & $\begin{array}{l}\text { Standard/control } \\
\mathbf{m g} / \mathbf{m l}\end{array}$ \\
$\begin{array}{l}\text { Staphylococcus } \\
\text { aureus }\end{array}$ & 14.00 & 10.00 & 8.00 & 6.00 & 18 (Erythromycin)
\end{tabular}

Key:-ETM= erythromycin;

$\mathbf{R}=$ Resistant Concentration of „a" control $=1 \mathrm{mg} / \mathrm{mL}$

Table 4. Antimicrobial activity measured by zone of inhibition $(\mathrm{mm})$ for methanol root extract of $\boldsymbol{A}$. chevalieri

\begin{tabular}{llllll}
\hline Microorganism & $100 \%$ & $80 \%$ & $60 \%$ & $40 \%$ & $\begin{array}{l}\text { Standard/control } \\
1 \mathrm{mg} / \mathrm{ml}\end{array}$ \\
$\begin{array}{l}\text { Staphylococcus } \\
\text { aureus }\end{array}$ & 11.00 & 10.00 & 9.00 & 7.00 & 18 (Erthromycin)
\end{tabular}

\footnotetext{
Key:-ETM= erythromycin;

$\mathbf{R}=$ Resistant Concentration of „a" control $=1 \mathrm{mg} / \mathrm{mL}$
}

Table 5. Determination of MIC, MBC, and value for leaf extract Albizia chevalieri

\begin{tabular}{lll}
\hline Microorganism & $\mathrm{MIC}(\mathrm{mg} / \mathrm{mL})$ & $\mathrm{MBC}(\mathrm{mg} / \mathrm{mL})$ \\
Staphylococcus aureus & 6.25 & 12.5 \\
\hline \multicolumn{1}{c}{ Determination of } & MIC, MBC, value for root extract of Albizia chevalieri \\
\hline Microorganism & $\mathrm{MIC}(\mathrm{mg} / \mathrm{mL})$ & $\mathrm{MBC}(\mathrm{mg} / \mathrm{mL})$ \\
Staphylococcus aureus & 6.25 & 10.5 \\
\hline
\end{tabular}

Table 6. Determination of MIC, MBC, value for leaf extract of Kigeli africana

\begin{tabular}{lll}
\hline Microorganism & $\mathrm{MIC}(\mathrm{mg} / \mathrm{mL})$ & $\mathrm{MBC}(\mathrm{mg} / \mathrm{mL})$ \\
Staphylococcus aureus & 6.25 & 12.5 \\
\hline
\end{tabular}

Determination of MIC, MBC, value for root extract of Kigeli africana

\begin{tabular}{lll}
\hline Microorganism & $\mathrm{MIC}(\mathrm{mg} / \mathrm{mL})$ & $\mathrm{MBC}(\mathrm{mg} / \mathrm{mL})$ \\
Staphylococcus aureus & 6.25 & 12.5 \\
\hline
\end{tabular}

The table 5 and 6 shows the MIC and MBC value of 6.25 and $12.5 \mathrm{mg} / \mathrm{mL}$ against Staphylococcus aureus for leave extract and 6.25 and 10.5, 6.25 and $12.5 \mathrm{mg} / \mathrm{mL}$ against Staphylococcus aureus for root extract tested listed in the Table above. 


\section{DISCUSSION}

Albizia chevalieri and Kigelia africana were extensively used in the management of various infections and allergic diseases. The ethanol extract of both plants were tested against the organism namely Staphylococcus aureus. The zone of inhibition of both plant extracts at $100 \%$ concentration were; table 1 for leaf of $K$. africana $20 \mathrm{~mm}$, table 2 for leaf of $A$. chevalieri $16 \mathrm{~mm}$, table 4 for root of same plant $11 \mathrm{~mm}$, and table 3 for root of $K$. africana $14 \mathrm{~mm}$, respectively. The below antimicrobial test result shows the susceptibility test against Gram positive bacteria (S. aureus).

The ethanol extract exhibited a considerable level of inhibition against the test organism compared to the standard drug at $100 \%$ concentration, table $\mathbf{1}$ and table 2, which is suggestive of the presence of some compounds or groups in the extract with similar mechanism of action to that of standard drug used in bacterial activity (Saha and Ahmed, 2009). Various works have already shown that Gram positive bacteria are more susceptible towards plant extracts as compared to the Gram negative bacteria (Hassan and Oyewale, 2004). These differences may be attributed to the fact that the cell wall in Gram positive bacteria is of a single layer, whereas the Gram negative cell wall is a multilayered structure. Alternatively, the passage of the active compound through the Gram negative cell wall may be inhibited. At 100\% concentration, Table $\mathbf{3}$ and $\mathbf{4}$ show less antimicrobial activity as compared to the standard drug.

\section{Comparing the efficacy of the root and leaves of $K$. africana and A. chevalieri}

In addition microorganism show variable sensitivity to chemical substances related to different resistance levels between strains (Meda, 2005); the highest activity was exhibited by crude extracts of both plants with the leaf of $K$. africana showing a considerable zone of inhibition as compared to the leaf of $A$. chevalieri (Table 1 and 2). While the root of $A$. chevalieri having less activity compared to that of $K$. africana (Table 3 and 4). Considering the zone of inhibitions, the leaf and root extract of $K$. africana show high zone of inhibition and exhibit more activity while that of A. chevalieri also show antimicrobial activity with a zone of inhibition greater than $10 \mathrm{~mm}$.

Comparing their efficacy in terms of antimicrobial activities shown by both plant extracts, one can say that both plant extracts exhibited antimicrobial activity with root of $K$. africana showing more activity as compared to the root of $A$. chevalieri (table 3 and 4 ).

The pharmacology of $A$. chevalieri showed that it possesses anti-microbial, anti-histamine and mast cell stabilizing properties (Graceline, et al., 2013) and it agrees with this study on the anti-microbial activity showed by the plant extract. Also the leave extract of $A$. chevalieri has been reported for effective anti-bacterial and anti- candida activity from Brazilian flora (Tempone et al., 2008) because of the presence of active compounds (alkaloids, aminoacids, saponins, flavones, Quinone's, tannins, carbohydrates) and this is also in agreement with the anti-bacterial activity exhibited by the plant extract of $A$. chevalieri in this study.

Therefore this suggests the efficacy of both plants in pneumonia, bacteremia, and urinary tract infections. However, it may be suggested that plant extracts exhibiting diameter of zones of inhibition greater than $10 \mathrm{~mm}$ is considered as active (Usman and Osuji, 2007). Thus it is believed that plant extracts is better antimicrobial agents for various pathogenic bacteria.

$K$. africana plant extracts has many medicinal properties due to the presence of numerous secondary metabolites e.g. iridous, naphthaquinoid, flavonoids, coumarone, lignin's, saponins, tannins, alkaloids, phenol etc. Some researchers demonstrated its activity as mild (Sikder, 2011). Previous investigations of $K$. africana have established anti-microbial activity of the leaves and stem back against $S$. aureus, E. coli and Candida albicans (Akuyili, et al., 1991; Kwo and Craker, 1996). And this also agrees with this study as ant-microbial activity against $S$. aureus was observed.

Moreover, the methanolic extract from the bark showed significant activity against Salmonella typhi and Proteus vulgaris but poorly active against Escherichia coli, Enterobacter aerogens, Klebsiella pneumoniae, Pseudomonas aeruginosa, Staphylococcus aureus and Bacillus cereus (Jeyachandran, 2007).

Binutu, et al (1996) reported that extracts of $K$. africana roots showed anti-bacterial activity against $S$. aurues, Bacillus subtilis, and anti-fungi effect against candida albicans. This is in agreement with the reputed potency of $K$. africana root and leaf against common bacterial complaints.

\section{MIC and MBC}

The antimicrobial activity showed the MIC of $6.25 \mathrm{mg} / \mathrm{ml}$ against $S$. aureus and MBC of 10.5 and $12.5 \mathrm{mg} / \mathrm{ml}$ against test organism (Table 5 and 6).

The low MIC value observed for $S$. aureus is a good indication of high efficacy against this bacterium. This outcome is remarkable considering that boil, breast abscess and surgical wound infection etc. (caused by $S$. aureus) 
is on the rise and also becoming recalcitrant to first-line antibiotics for its treatment in developing countries, including Nigeria. High MIC may be an indication of low efficacy or that the organisms have the potential for developing resistance to the bioactive compounds.

Conclusively, Albizia chevalieri and Kigalia Africana should be considered as a promising plant with various therapeutic properties and can be further explored pharmacologically against various ailments and for free- radical mediated diseases; therefore this would open-up a refreshing study about the immense utility of Albizia and Kigalia and encourages the phytochemists to drive on the rest of the species. Additionally, the failure of alternative drug discovery methods to yield useful drugs in key therapeutic areas makes medicinal plants research a viable option despite inherent limitations (Karuppannan, et al., 2013).

\section{REFERENCES}

Ahmed, M., Djebli, N., Meslem, A. and Aisshat, S (2012). Antibacterial activity of various honey types of Algeria against Pathogenic Gram-Negative Bacilli: Escherichia coli and Pseudomonas aeruginosa. Asian Pac. J. Trop. Dis.; (3): 211-214.

Akunyili, D.N., Houghton, P.J. and Raman A (1991) Antimicrobial activities of the stem bark of Kigelia pinnata. J. Ethnopharm; 35: 173-177.

Ankit, G., Madhu, N. and Vijay, K (2012): Extraction Methods for the Preparation of Bioactive Plant Extracts. Intl. J. Appl. Nat. Sci.; 1(1):8-26.

Azuine, M.A., Ibrahim, K., Enwerem, N.M., Wambebe, C. and Kolodziej, H (1997) Protective role of Kigelia africana fruits against benzo[a]pyrene-induced for stomach tumourigenesis in mice and against albumen-induced inflammation in rats. Pharmaceutical and Pharmacological Letters 7: 67-70.

Binutu, O.A., Adesogan, K.E. and Okogun, J.I (1996) Antibacterial and antifungal compounds from Kigelia pinnata. Planta Medica 62: 352-253.

Burkill, H.M. (1995). The Useful Plants of West Tropical Africa Vol. 3. Families J-L, Royal Botanical Gardens, Kew. Pp. 207-208.

Constantine, D.S (2007). Extraction, Separation and Detection Methods for Phenolic acids and Flavonoids. J. Sep. Sci. 30:3268-3295.

Ekeanyanmu, C.R (2011). Traditional Medicine in Nigeria; Current Status and the Future. Res. J. Pharm.; 5(6):90-91

Eloff, J.N (1998). Which extract should be used for the screening and isolation of antimicrobial compounds from plants. J. Ethnopharm. 60:1-8.

Gracelin, D.H.S., De-Britto, A.J., Jeya, P.B. and Kumar, R (2013). Qualitative and Quantitative Analysis of Phytochemicals in Five Pteris species. Intl. J. Pharm. and Pharmacl. Sci.; 5(1):105-107

Hassan, M.M., Oyewale, A.O., Amupitan, J.O., Abduallahi, M.S. and Okonkwo, E.M. (2004). Preliminary phytochemical and antibacterial investigation of crude extracts of the root bark of Detarium microcarpum. J. Chem. Soc. Nigeria.; 29: 26-29.

Hemendra, S.C. and Sushil, K.S (2010). Antibacterial Activity of Seed and Flower Parts of Crotalaria juncea Linn. Am.-Eurasian J. Sci. Res. 5(3):212-215

Igidi, O.J. and Edene, C.E (2014). Proximate and phytochemical compositions of Napoleona vogelii hook fruit. Intl. J. Engr. Sci.; 6:46-51

Jeyachandran, R. and Mahesh, A (2007). "Antimicrobial evaluation of Kigelia africana (Lam)." Res. J. Microbiol., vol. 2, pp. 645-649.

Karuppannan, K., Subramanian, D.P. and Venugopa, S (2013): Phytopharmacological Properties of Albizia Species. Intl. J. Pharm. Pharmacal. Sci. 5(3):70-73

Khan, M.R (1998) Cytotoxicity assay of some Bignoniaceae. Fitoterapia 69: 538-540

Kwo, V.T. and Craker, L.E (1996) Screening Cameroon medicinal plant extracts for antimicrobial activity. Acta Horticulturae 426: 147-155.

Meda, A., Lamien, C.E., Romito, M., Millogo, J. and Nacoulma, O.G (2005). Determination of the total phenolic, flavonoid roline contents in Burkina Fasan honey, as well as their radical scavenging activity. Food Chem.; 91: 571-577.

Nascimento, G.G.F., Lacatelli, J., Freitas, P.C. and Silva, G.L (2000). Antibacterial activity of plant extracts and phytochemicals on antibiotic-resistant bacteria. Braz. J. Microbiol. 31(4): 886-891.

National Committee for Clinical Laboratory Standard (1990). Methods for the antimicrobial susceptibility testing. In: Manual of Clinical Microbiology. Am. Soc. Microbiol. Washington, DC. 5th edition, pp. 1105-1125.

Owolabi, .J. Omogbai, E.K.I.and Obasuyi, O (2007). Antifungal and antibacterial activities of the ethanolic and aqueous extract of Kigelia africana (Bignoniaceae) stem bark. Afr. J. Biotechnol. 6 (14): 882-85. 
Prashant, T., Bimlesh, K., Mandeep, K., Gurpreet, K. and Harleen, K (2011): Phytochemical Screening and Extraction; A Review. Internationale Pharmaceutica Sciencia, 1(1):98-106

Retief, E. and Herman, P.P. J (1997) Plants of the Northern Provinces of South Africa: Keys and Diagnostic Characters. National Botanical Institute, Pretoria, South Africa. ISBN 874907-30-7

Saha, A. and Ahmed, M (2009). The analgesic and anti-inflammatory activities of the extract of Albizia lebbeck in animal model. Pak. .J Pharm. Sci.; 22(1): 74-77.

Sikder, M.A.A.A., Hossain, A.K.M.N., Kaisar, M.A., and Rashid, M.A (2011). "in vitro anti-microbial screening of four reputed medicinal plants." Pharmaco. J., vol.3, 2011, pp.72-76.

Tempone, A.G., Sartorelli, P., Teixeira, D., Prado, F.O. Calixto, I.A.R.L., Lorenzi, H. and Melhem, M.S.C. (2008). Brazilian flora extracts as source of novel antileishmanial and antifungal compounds, Mem. Inst. Oswaldo Cruz, 103(5): 443-449.

Usman, H. and Osuji, J.C. (2007). Phytochemical and in vitro anti-microbial assay of the leaf extract of New bouldia leavis. Afr. J. Trad. Med. 4: 476-480.

Yusuf, S., Lawal, S.B., Mansur, L., Simeon, A.I. and Rabiu, A.U. (2007): Hematotoxicity study of the leaf extract of Albizia chevalieri (Harms) (leguminoseae). Biochemia medica, 17(2):203-211.

Cite this Article: Samaila AB, Yarma AA, Oshomoh EO and Gabriel M, 2014. Antimicrobial Activity of the Leaf and Root Extracts of Kigelia africana and Albizia chevalieri against Staphylococcus aureus. Greener Journal of Microbiology and Antimicrobials, 3 (1): 001-007. http://doi.org/10.15580/GJMA.2017.1.012517009 